Review

\title{
Retrospecting National Unity, Safety and Security in India: Foraging an United Nationhood
}

\author{
${ }^{1}$ Sambeet Satapathy and ${ }^{2}$ Sandeep Satapathy \\ ${ }^{I}$ Department of Biotechnology, College of Engineering and Technology, Bhubaneswar, India \\ ${ }^{2}$ Department of Biological Sciences, Indian Institute of Science Education and Research, Bhopal, India
}

Article history

Received: 25-04-2015

Revised: $18-08-2015$

Accepted: 22-10-2015

Corresponding Author:

Sandeep Satapathy

Department of Biological Sciences,

Indian Institute of Science

Education and Research, Bhopal,

India

Email: satapathys@live.in

\begin{abstract}
Unlike many other developing nations India experiences a unique spatio-temporal cultural, economic, political diversity both natural and manmade. It is thus important to understand the source of national identity, the centripetal force that has held all the elements together. Historically exposure to various unifying forces in form of kingdoms and empires both native and foreign has contributed much to its composite culture. India exhibited exceptional tolerance and collaboration. The struggle for independence further strengthened the national identity which was later reaffirmed by the constitution of India. However, certain contemporary issues like lop sided development and disparities, extreme regionalism, insurgency, left wing extremism and ethnic discrimination and violence have challenged the national unity and endangered safety and security. The paper strives to redefine the existing ideologies and social norms of national unity. However, we suggest reinforcing national unity by inclusion of a cultural, political and economic unity to forge a united nationhood both in concept and practice.
\end{abstract}

Keywords: India Unity, Secularism, Socialism, Sovereignty, National Unity and Security

\section{Introduction}

For a country as vast as India, diversity is the longitudinal local time difference of two hours with its vast span of geographical boundaries. Beyond this spatio-temporal diversity of place and time, with climate ranging from alpine to tropical rainforests and approximately twenty-two national languages and numerous dialects spoken, several new dimensions get added to the diversified image of the unified nation. Geopolitically, it consists of twenty-nine states of which few are as vast and populous than several important European countries (Banks, 2007; Bopegamage, 1971). Economically, states like Maharashtra and Gujarat thrive on modern capitalist modes of production, states of Madhya Pradesh, Bihar and Odisha still are largely dependent on agricultural economy. However, the starking reality is that still regions like Vidharba in Maharashtra and KBK in Odisha have witnessed drought, famine, hunger and mortality.

This diversity Sui-generis raises in mind the question that what holds India as a nation? Is it the shared political belongingness to one state or the composite cultural heritage or the spirit of nationalism rooting from our past struggle for independence? The question that still is a debate is what gives India the identity of a nation and keeps it united despite of its natural and manmade diversities. Literature review clearly establishes the fact that India being one of the oldest civilisations of the world has several mythological and cultural viewpoints of national unity that has shaped and restruced our contemporary idealogical interpretation of a nation. Perhaps travelling back in time and exploring the history of making of this nation, one can observe a succession of events where India was ruled by different dynasties of rulers including the Mughals, the Kushanas, the Mauryas, the Lodhis and the Britishers (Brass, 1991; 1994; 2005). Although many of these rulers were native, still India has also faced the exposure of new cultures, languages and life-styles from those rulers who belonged to foreign land. However, the introduction and amalgamation of the foreign culture, polity and economy to our indigenous counterparts was indeed a 
slow and passive process (Brass, 1994). Ultimately, different equations of blending were set for different regions of India and what ushered in the postindependence era was a civilization that paved the path for today's India (Bulag, 2002). The modern, dynamic and independent civilisation has glimpses of socioeconomic diversity and rich culture with high degree of tolerance for the existing and inherited differences in the society (Chaturvedi, 2002).

However much to its credit, the period of British rule in India led to the extensive rise of the spirit of nationalism which transcended the geographical boundaries, primordial identities of caste and religion to forge a united front to overthrow the colonial rule. The constitution of India, has very precisely captured this spirit and celebrated the identity of being a united nation by mentioning in its preamble to secure all its citizens fraternity as well as securing the unity and integrity of nation (Desai, 2005; Goswami, 2004; Kochanek and Hardgrave, 2007). A secular country with equal respect, tolerance and cooperation towards all religions, tribal autonomy and rights with guarantee of full participation in the broad socio-cultural polity are indicators of the modern united India (Desai, 2005). In addition to the existing provisions and several instances of subsequent amendments for ensuring effectiveness of federal polity (Goswami, 2004), three tier system of government, All India services, integrated judiciary (Kohli, 2001), Single citizenship and freedom of trade, commerce and habitation (Krishna, 1996) have further consolidated the striving efforts of this developing nation for promoting united nationhood over prevailing regionalism, extreme nationalism, fascism and aggressive expansionism.

Indeed it was a moment of pride for the whole nation to recall the process of nation building and commemorating the birth anniversary of the greatest "Bismarck of the east" Sardar Vallabh Bhai Patel by celebrating the day as National Unity Day. He displayed the courage to integrate and merge the puzzle pieces of five hundred fifty-two odds of princely states into the erstwhile independent India (Krishna, 1994; Ludden, 2005). Further, restructuring of All-India services with a vision to implement centralised recruitment and training to ensure highest standards of service to the states was another such achievement of the nation under his leadership (Ludden, 2005). He envisioned and translated into reality his dream of transforming small states into viable economy and cultural units based on linguistic identities where developmental goals were largely sustainable for the state and the nation as a whole (Mason, 1967). Today, when the country identifies Sardar Patel as the nation's figure of unity, it's an achievement of every citizen of the nation who has carried and maintained the feeling of a strong, secular and largest federal polity of the world. Therefore, fostering national unity in terms of collective national identity calls for social reforms and ideological innovations. Strategic and social policy implementation and their successful access by the citizens irrespectiev of caste, cree and gender holds the true spirit of national unity and identity. Thus, in this study we address the exisiting social challenges to this fast developing nation, where questions pertaining to basic livelihood and national security still remian loud but largely unheard.

\section{Issues Infesting India's National Unity}

In the contemporary context where India is tailoring its external affairs and foreign policies to maintain a congenial international relation, the ongoing boundary disputes with some of the neighbouring nations still questions the nation's identity. It's safe to assure that once we are integrated into the territory of a sovereign state, we have also achieved "nationhood". With the ongoing debate on whether India is a state or a nation; newer challenges to national unity have emerged both from within and without.

"The biggest threat of a small country is its powerful neighbour and for a big country as like India is its internal vice-Voltaire." Chinese expansionism, illegal occupation of the Aksai-Chin area in Jammu and Kashmir, claims over Arunachal Pradesh (Mason, 1967), Pakistan's illegal claim and occupation of the areas of Jammu and Kashmir (Mookerji, 2004; Nehru, 1938) are some of the leading instances of growing separatism and cross-border national insecurity. Terrorism has been another big issue that India has been fighting for several decades and on several instances enormous wealth and human resource of the country have been sacrificed in this national fight against terrorism.

Infiltration (Nehru, 1938), illegal immigration, drug and arms trade (Mookerji, 2004), counterfeit currency and translational organised crime have put our national security in a jeopardy. Within the country post globalization, India has witnessed a lopsided development where stark regional disparities with demands for land reforms (Mason, 1967), political participation and autonomy taking militant forms across the country. The "red corridor" consisting of the thick forested area of the nine backward and agricultural states of India are infested with left wing extremism (Patel and Chopra, 1990). Political apathy to the needs and aspirations of the backward regions of the country, poverty, unemployment (Nehru, 1938; Varshney, 2003), deprivation and development led displacement (Varshney, 2003) have all served as impediments to national unity which is essential for security and safety of the nation. Regionalism and identity politics too have led to infusion of parochial notion of regional interests 
over the broad national interests. Hate crimes, ethnic discrimination against people from north east have been widespread. Similary, incidences of exploitation and violence against migrant working population from the poorer states of the nation like Uttar Pradesh, Bihar and Odisha have been reported (Patel and Chopra, 1990).

\section{Future Prospective of Building National Unity}

It is truly felt that in the contemporary world and Indian society national unity is indispensable towards safety and united development of the nation. It is felt that state, civil society and international community should work towards promoting harmony and unity to transform political states into true nation-states. Reflecting on the vision and pragmatism of the "iron-man" of India, to the neutralise the threats to national unity progressive steps like uniform civil code and revision of article 370 regarding special status of Kashmir to reflect the geopolitical reality is required. Border disputes must be resolved bilaterally on the basis of fair, reasonable and mutually acceptable grounds. Several exisiting theories of trans boundary agreement and peace settlement between India and its beighbouring countries has always highlighted our unique approach of building a peaceful place to live in with integrity and harmony. The recent Land boundary agreement between India and Bangladesh to converge the existing enclaves into territorial limits and give the enclave dwellers right to choose their nationality has been a historic movement in resolving boundary disputes and proclaiming national unity. However, although several such policies are based on social theories like melting pot theory, but the adaptiveness of these theories need to be examined and curcumstancially restructred to encompass a practical national identity. This not only requires vision but also courage from the state. Similarly, regional disparities and lopsided development needs to be addressed with simultaneous leveraging of national efforts to combat left-wing extremisim. Internal peace of the nation calls for more focus of the government on addressing critical issues of poverty and unemployment. The key for widely-felt national unity relies on participative governance where the voice of powerless and backward sections make their distinct presence.

\section{Conclusion}

Only when a nation stands united, it can prosper and its citizens can be safe and secure. The notion of national unity in the contemporary world has to transcend the narrow definition of territorial integrity and should encompass what Sardar Patel envisioned as cultural and economic unity, tolerance, respect and cooperation among and across diverse regional, ethnic, linguistic, religious and caste diversity.

\section{Acknowledgment}

The authors take this opportunity to thank Dr. Prativa Mahapatra for her expert guidance and technical information in collating informations required for this paper.

\section{Conflict of Interest}

The authors declare no conflict of interest with any associated funding bodies or any institution or person with the preparation of this manuscript.

\section{Author's Contributions}

Sambeet Satapathy: Contributed in developing the topic and the content of this paper along with analysis of the issue from a critical perspective.

Sandeep Satapathy: Contributed in developing the analsyed data into the concept required for publication along with systematic presentation of the facts in this paper.

\section{References}

Banks, J.A., 2007. Diversity and Citizenship Education: Global Perspectives. 1st Edn., John Wiley and Sons, Incorporated, ISBN-10: 0787966517, pp: 485.

Bopegamage, A., 1971. The military as a modernizing agent in India. Economic Dev. Cultural Change, 20: 71-79. DOI: $10.1086 / 450530$

Brass, P.R. 2005. Language, Religion and Politics in North India. 1st Edn., iUniverse, Lincoln, ISBN-10: 0595343945, pp: 484.

Brass, P.R., 1991. Ethnicity and Nationalism: Theory and Comparison. 1st Edn., Sage Publications, ISBN-10: 8170362393, pp: 358.

Brass, P.R., 1994. The Politics of India since Independence. 1st Edn., Cambridge University Press, ISBN-10: 0521459702, pp: 403.

Bulag, U.E., 2002. The Mongols at China's Edge: History and the Politics of National Unity. 1st Edn., Rowman and Littlefield, Lanham, ISBN-10: 0742511448, pp: 273.

Chaturvedi, S., 2002. Representing Post-Colonial India: Inclusive/exclusive Geopolitical Imaginations. In: Geopolitical Traditions: Critical Histories of a Century of Geopolitical Thought, Atkinson, D. and K. Dodds (Eds.), Taylor and Francis, London, ISBN-10: 0203449118.

Desai, A.R., 2005. Social Background of Indian Nationalism. 6th Edn., Popular Prakashan, ISBN-10: 8171546676, pp: 437.

Goswami, M., 2004. Producing India. 1st Edn., Orient Blackswan, New Delhi, ISBN-10: 8178241072, pp: 401. 
Kochanek, S. and R. Hardgrave, 2007. India: Government and Politics in a Developing Nation. 7th Edn., Cengage Learning, Boston, ISBN-10: 0495007498, pp: 560.

Kohli, A., 2001. The Success of India's Democracy. 1st Edn., Cambridge University Press, ISBN-10: 0521805309, pp: 298.

Krishna, B., 1996. Sardar Vallabhbhai Patel, India's Iron Man. 1st Edn., Indus, New Delhi, ISBN-10: 817223211X, pp: 567.

Krishna, S., 1994. Cartographic anxiety: Mapping the body politic in India. Alternatives, 19: 507-521.

Ludden, D.E., 2005. Making India Hindu: Religion, Community and the Politics of Democracy in India. 2nd Edn., Oxford University Press, Delhi, ISBN-10: 0195672488, pp: 350.
Mason, P., 1967. India and Ceylon: Unity and Diversity: A Symposium. 1st Edn., Oxford University Press.

Mookerji, R.K., 2004. The Fundamental Unity of India. 1st Edn., Orient Blackswan, New Delhi, ISBN-10: 8180280055, pp: 148.

Nehru, J., 1938. The unity of India. Foreign Affairs, 16: 231-243. DOI: $10.2307 / 20028844$

Patel, V. and P.N. Chopra, 1990. The Collected Works of Sardar Vallabhbhai Patel. 1st Edn., Konark Publishers, Delhi, pp: 375.

Varshney, A., 2003. Ethnic Conflict and Civic Life: Hindus and Muslims in India. 1st Edn., Yale University Press, New Haven,

ISBN-10: 0300100132, pp: 382. 